\title{
What universities in the Middle East can learn from the American online education system
}

\author{
Mahmoud Al-Odeh \\ School of Technology, Art and Design, Bemidji State University, USA
}

\begin{tabular}{l}
\hline \hline Article Info \\
\hline Article history: \\
Received Oct 11, 2019 \\
Revised Nov 13, 2019 \\
Accepted Jan 12, 2020 \\
\hline
\end{tabular}

Keywords:

Adoption model

Middle east

Online education

Quality online education

Stratgy

\begin{abstract}
In this paper, the author provides insights and lessons that can be learned from colleagues at American universities about their online education experiences. The literature review and previous studies of online educations gains are explored and summarized in this research. Emerging trends in online education are discussed in detail, and strategies to implement these trends are explained. The author provides several tools and strategies that enable universities to ensure the quality of online education. At the end of this research paper, the researcher provides examples from Arab universities who have successfully implemented online education and expanded their impact on the society. This research provides a strategy and a model that can be used by universities in the Middle East as a roadmap to implement online education in their regions.
\end{abstract}

This is an open access article under the CC BY-SA license.

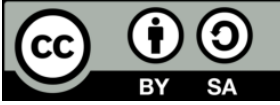

\section{Corresponding Author:}

Mahmoud Al-Odeh,

School of Technology, Art, \& Design,

1500 Birchmont Dr NE, Bemidji, MN 56601, United State of America.

Email: Mahmoud.Al-Odeh@Bemidjistate.edu

\section{INTRODUCTION}

With the advance of emerging instructional technologies, online education has become a popular option in the United States (U.S). Online education is a learning technique that uses the World Wide Web (WWW) and its applications to deliver the content of a learning session or training. The flexibility and other advantages provided by online education has encouraged American students to take classes via the Internet. In the same way, American universities have used online education as one way to survive budget cuts and economic recessions by reducing their needed physical resources, such as labs and buildings [1, 2].

Successful experiences of online education in American universities and those around the world continue to support its growth and, therefore, have also increased the budget allocation for online education programs [3]. The success of online education has even encouraged traditional universities to replace their traditional campuses and programs with virtual campuses by creating environments of online or blended classes.

In 2015, Babson Survey Research Group conducted a study about online education in the U.S and found that university leaders consider online learning a crucial strategy to their institutional growth, and this perspective has increased from $48.8 \%$ in 2002 to $70.8 \%$ in 2015 [4]. This percentage dropped in 2016 to $63.3 \%$ [5]. In a study conducted by the U.S. Department of Education (2010), it was found that students in online courses performed better than students who were enrolled in face-to-face courses [6]. The study also found that learning outcomes for online learning exceeded those of face-to-face classes. The study recommended using technologies in on-campus classes to achieve the highest benefits from learning outcomes [6]. These types of classes are called blended or hybrid. It was estimated, in a study conducted by the National Center for Education Statistics (NCES), that $28.5 \%$ of American students take online learning 
courses at the postsecondary level [7]. Docebo [8] predicted that the market for online learning would grow by $5 \%$ between 2016 and 2023 .

The impact of online education has affected most universities in the world, including in the Middle East area. The impact of the online education movement is relatively low in the Middle East compared to the universities in the US. This low impact is due to the late adopting of the Internet and its technological infrastructure in these countries [8]. However, some universities have been trying very hard to keep up with this new trend in education. In 2013, the Minister of Higher Education at the United Arab Emirates (UAE) considered interactive online education equivalent to traditional education programs [9]. On the other hand, other countries in the Middle East are still not accepting the idea of online degrees, and they are considering that this type of education is low quality compared to traditional education $[10,11]$. Therefore, these countries would not approve online degrees as equivalence to traditional ones. The reality is that online courses are considered more challenging than traditional ones [12]. For example, to ensure students engagement, online faculty require more reading activities than the ones required in traditional courses.

This research provides a strategy and a model that can be used by universities in the Middle East as a roadmap to implement online education in their regions. The model is built based on reviewing best practices in American universities. The researcher is hoping to solve the problem of slow adoption of online education in Middle East universities. The reasons for the slow adoption are explained in the discussion section. To solve this problem, a strategy and model is proposed in this research to provide systematic method to guide education leaders in the Middle East to implement online education.

\section{ONLINE EDUCATIONS GAINS AND BENEFITS}

There are many benefits and advantages that can be gained from online education. These gains are for students, faculty, and institutions. Online education helps students to have more control over their learning process, as they would start the lecture and course material at their convenience, and it is not restricted by time or physical location [13]. Students would be able to build a study schedule that suits them and based on their availability and, therefore, they would benefit more this way. Students in the rural areas would enjoy taking classes from home, as it would be challenging for them to attend an on-campus lecture. These gains are not available in traditional education.

The other benefit of online education from the students' perspective is the cost. Students enrolled in onlinee degrees can reduce the cost burden of education [14]. For traditional education, tuitions are not the only costs for credits. Other costs associated with traditional education are housing, food, and transportation [15]. With online education, these costs are eliminated due to the fact that students can take classes while they are sitting at home. Another important point related to the cost is that most institutions offer online courses for lower tuition compared to traditional education due to no physical resources needed for online students. Giving free laptops and all software needed to online students is a common practice in American universities [16]. This also adds savings for students who decide to enroll in online programs.

Diversity is another benefit of online education. A student can be part of a diverse group of students from all around the world [13]. This would help students understand other cultures' perspectives and norms. Diversity in a classroom would enable students to be open to new ideas, think out of the box, and become more creative, not restraining with their own ideas. Diversity is also essential to career preparation. Having students from all around the world would encourage students to enter the global job market and have better opportunities securing a high paid job.

Faculty can also benefit from teaching online courses in several ways. Faculty would have more time to engage in developing instructional activities, and this would result in improving their teaching performance [17]. Teaching from anywhere is another enjoyable feature that faculty can have if they decided to teach online courses [18]. They could travel to conduct research and, at the same time, teach classes online. The Internet has eliminated the restriction of having faculty physically exist in the building to teach classes. Online education provides faculty with flexibility and, therefore, faculty can efficiently manage their time and achieve more of their career and life goals. Technological tools can also save faculty time and become more efficient [19]. For example, online quizzes can be graded instantly, and no time is needed from faculty other than developing quizzes online. Effective feedback can also be easily provided online and within a reasonable period.

Students in online classes also have the opportunity to express their opinions freely without being shy, as they might be in a face-to-face class [20]. The rich discussion environment of an online course is replete with deeper and more reflective opinions [21]. Such an environment helps faculty to know students at a deeper level and build strong connections with them. This further helps faculty to evaluate students' performance in the virtual environment accurately. Having students from around the word participating in 
online classes also improves faculty communication skills by encouraging them to develop global communication techniques of thinking to address a global audience.

Public education institutions use online education to accommodate the demands of those who are interested in earning higher education credits [22]. This strategy eliminates the need for building new facilities to meet demand. Online education, in other words, helps institutions to expand and accept more students without the need to invest in physical facilities. In a 2025 strategic plan study conducted for the Florida State University System, it was estimated that the system would need \$184.3 million dollars to build classrooms for their face-to-face students in the next five years. This cost can be avoided by offering courses fully online [23].

There are countless benefits that can be gained from the online education. These benefits include increasing student access to learning material, improving student quality of learning, better preparing students for life skills, providing increased learning opportunities, and many more.

\section{THE LIMITATIONS OF ONLINE EDUCATION}

This section includes a discussion of the difficulties that may be faced when adopting online education from the viewpoints of students, faculty, and institutions. Students may have difficulty taking online courses due to a lack of readiness to address this learning environment [24]. Readiness is important to student success in online education. Readiness can be demonstrated by having the necessary technology (e.g., Internet access and a laptop) available to students and supporting their ability to use these technologies. Another aspect of readiness is self-discipline, or self-directed motivation. This means that students need to have excellent time management and organization skills to be able to finish coursework on time [13]. Having no direct connection with instructors and other students in the course makes online education difficult and requires relatively more patience when engaging in the course and its activities [25]. Students may also feel lonely and unsupported during the online learning process [26]. Their engagement and participation in class activities is completely self-directed, and no one can encourage them to participate but themselves. Finally, yet importantly, technical difficulties might cause frustration and discouragement for online students if there is no technical support available to them [27]. In synchronous classes and during real-time class activities, videoconference, software upgrades, plug-ins, and network issues may occur and prevent students from participating. Faculty, therefore, should be prepared to deal with these issues in order to enable students to participate in synchronous sessions.

Online environments are also challenging for faculty. Just as student readiness is key, faculty should also be ready to use the required technologies [28]. Workshops and training sessions are required to ensure faculty readiness to teach online classes. Faculty should be given the needed training and time to become proficient in using instructional technology and in becoming online developers and instructors [29]. Having faculty who are not fully trained to teach online courses may lead to ineffective learning experience due to poor course management and inadequate communication with students. Another important point is that faculty need adequate time to design online courses and prepare written or video instructions for their students [30]. This time can be part of the faculty teaching load, with no additional compensation offered. Institutions, however, may offer grants and incentives to have their faculty design and develop new online courses during the summer sessions. Responding to individual emails and communication is also time consuming and requires extra commitment from faculty to address students concerns [31]. Responses to students might not be instant, as instructors may take a few days to reply to them. Students, however, are usually looking for quick responses from their instructors, and late responses may discourage them from participation in the class or asking another question. If an online instructor has difficulty finding the time to respond to students' questions, this may affect students' engagement, as they could feel ignored.

The main challenge of offering online courses, from institutions' perspectives, is the high initial investment cost [23]. The first cost of implementing the online infrastructure and strategies is very high due to the time spent developing the course and the need for online tools. A cost-benefit study conducted by the University of British Columbia found that the first offering of one of their classes was $75 \%$ over budget [32]. This cost significantly decreased in subsequent offerings because most of the online infrastructure is in place, resulting in no need to invest in major tools until the next system upgrade, usually in 3-5 years. The cost also decreases when student enrollments increase for a specific course [30]. Additional costs are needed to offer training for faculty to gain new strategies for teaching online courses. Offering training for faculty is necessary because it increases the level of faculty readiness and ensures the effectiveness of the learning experience. Through such training, faculty are equipped to face challenges and provide a positive experience to their students. Online instructional technologies require institutions to hire a technical support team to help faculty and students with the challenges that they might face during their online journeys [33]. This additional cost is additional to the cost of online education, but it is necessary ensure a positive and 
engaging environment free of technical issues, especially in synchronous learning sessions. With rapid technological changes, institutions should be investing in the best online instructional technologies available. Therefore, it is necessary for institutions to have a clear plan for purchasing and upgrading their systems and technologies every three years, at the most, to gain the best advantages from technologies.

\section{EMERGING TRENDS IN ONLINE EDUCATION}

Online education emerged in the year of 1993 with the emergence of web services and the World Wide Web (WWW). Since then, the face of education, in general, and online education, in particular, have dramatically changed due to rapid developments in instructional technologies. Four of the newest trends in online education are discussed in this section.

Open Educational Resources (OER): One of the trends in education in general, and in online education, in particular, is toward making the educational material (e.g. technologies, media, and textbooks) available free of charge for all individuals who are interested in the subject [34]. One form of Open Educational Resources (OER) is the Massive Open Online Courses (MOOCs), an initiative that offered unlimited courses online. MOOCs started in 2011 when American universities began to offer courses on platforms such as Udacity [35]. There are thousands of courses available to students to be taken for free. These courses are designed by providing short video lectures, followed by automated multiple-choice quizzes, to ensure students' understanding of the module content.

Fee-based completion and assessment: These type of online courses are designed for students who want to earn certificates of completion for a course or training [36]. They are offered with inexpensive fees. This type of learning allows potential students who are thinking about advancing their careers to sample courses by enrolling in certificate or degree programs. Examples of organizations that offer this type of education are coursera.org and udemy.com. Course fees range from $\$ 10.99$ to $\$ 100$ [36].

Social media and mobile applications integrations: Social networks have affected people's lives. Connecting electronically with friends and family has become one of life's necessities. Online education has invested in customizing mobile applications and social media to be used in the classroom. Desire to Learn, Blackboard, and Canvas are all Learning Management Systems that have iOS and Android apps available to students [37-39]. These LMS platforms are also available in instructional versions to grade students' work and provide feedback. With easy to access these applications, students can complete courses using their phones. The need for more friendly interfaces is one of the current challenges with these applications.

ADA Compliance \& accessibility: More than 15 university in the U.S. had to resolve complaint regarding the incapability of their students to access technologies and information used in their online courses [40]. The Americans with Disabilities Act 1990 and its 2008 amendments require instructional technologies and course material used by colleges and universities be accessible to all students including those with disabilities [40]. New trend in online courses these days is providing accommodation to all students who are enrolled in online classes including individuals with disability. Accommodation is enforced by implementing strategies such as providing alternative text, including links description, captioning videos, and transcribing audio [41].

Time to Graduation: time to finish a degree is a concern in higher education [42, 43]. It is considered as critical factor for educational institutions success. Therefore, policy makers and educators in the U.S. and other countries have created learning options to reduce time to graduation rate. These options include online courses, $2+2$ or $3+1$ programs, competency-based learning, prior learning experience credits, and personalized learning. Online classes also helped in reducing the time to graduate. Offering online summer classes enabled traditional students to register for classes during the summer while they are enjoying their time with their family.

\section{THE QUALITY OF ONLINE EDUCATION}

Flexibility in learning provides a great advantage to students, but the high quality and effectiveness of courses are also important to them and to industry. With the growth of online education, policies, standards, and guidelines have been created to ensure the rigorous application of the education process. The following are some of the practices that are used to ensure high quality online education:

Accreditation: Accreditation is one tool of evaluation that ensures the high quality of online programs. Accrediting agencies develop standards to evaluate the level of quality of online programs [44]. The accreditation team uses sets of standards related to such areas as academic and student support, technical support, faculty credentials, technological infrastructure, faculty and student resources, and administrative resources. Accreditation improves the reputation of institutions, and this helps to improve the enrollment rates, as students prefer to enroll in programs that are accredited over programs that are not [45]. 
Quality assessment measures: Quality Matters (QM) is a non-profit organization that has created assessment rubrics and measures to evaluate the quality of online courses [44]. QM rubrics consist of 43 specific review standards addressing areas such as learning objectives, assessment and measurement, instructional materials, learner engagement and interaction, and course technology. Three trained reviewers conduct the QM review process. The reviewers evaluate courses from students' perspectives and then provide suggestions on how to improve them. Figure 1 explains the QM review process for online and blended courses:

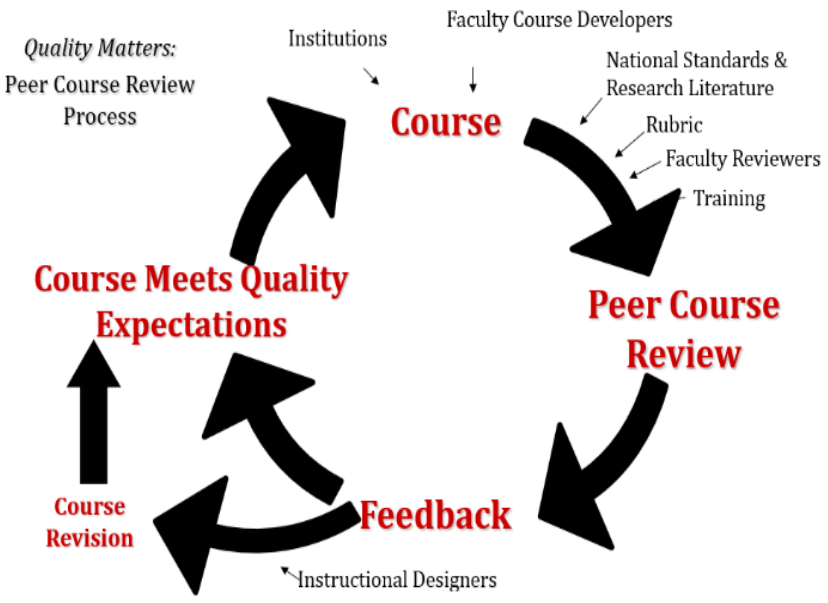

Figure 1. Quality Matters Review Process

Other institutions have created tools to evaluate the quality of online courses. The Online Learning Consortium, for example, is another non-profit organization that has had a significant effect on improving online education. Additional tools that have been developed to monitor course quality are Universal Design Online Content Inspection Tool (UDOIT) and Illinois Online Network Quality Online Course Initiative Rubric.

\section{RESULTS AND DISCUSSION}

The status of online education adoption process in Middle East is discussed in this section by providing examples from two countries. In addition, the proposed solution for the problem is explained using a strategy and a graphical mode.

\subsection{Examples from the Middle East}

The adoption of online education in the Middle East is slow compared to in the US and western countries. This slow process has been due to several reasons:

- Late adoption of the Internet and other technology infrastructures,

- The belief that traditional education is of better quality than online education,

- Lack of understanding of online education's advantages,

- The belief that on-campus resources and infrastructures are enough for the demand and that there is no need for supplemental solutions such as offering online education,

- Corruption and bureaucracy hinder establishing online programs.

Despite the slow adoption of online learning in the Middle East, these days there is a better understanding of online education and its need to make an impact on the education sector. Many Middle Eastern countries are considering this learning option, and many universities have hosted conferences related to online learning. The next section provides a discussion of two examples of Arab countries that have implemented online education successfully.

\subsubsection{United Arab Emirate (UAE)}

Hamdan Bin Mohammed Smart University Dubai (HBMSU) is the first virtual institution in the Arab world, established in 2002 [46]. The Ministry of Higher Education in the UAE accredited HBMSU as a research university [47] that offers learning experiences using advanced technologies such as mobile learning, online classrooms, discussion blogs, simulation games, and social networking. The university 
underwent numerous challenges before implementing online education successfully. The first phase was pursuing their accreditation. When the university started in 2002, the Ministry of Higher Education and Scientific Research (MOHESR) did not have accreditation standards for online programs. Therefore, HBMSU had to partner with the University of Bradford, UK, to offer joint programs until new accreditation standards were released in 2005 [48]. The university convinced MOHESR that online learning had a positive impact on education in the UAE and in the Arab world. The university received accreditation and approval of their programs in 2006 [49].

The second phase was to train traditional faculty in using instructional technologies and online tools. Faculty redesigned their courses using advanced technologies to meet the needs of their programs. The third phase was supporting and motivating traditional students during the online learning process [48]. Getting students adapted to the new environment requires changing their learning behavior from the traditional learning environment to an environment that encourages students to discover, construct, transform, and retain knowledge. In order to provide technical support for learners and faculty, the university created an in-house information technology department. The forth phase was Arabization of knowledge, which involved translating textbooks into Arabic. In this phase, the university established a publishing venue to help them create course content, material, and textbooks to learners in their mother language $[48,50]$. The last phase was monitoring, controlling, and improving the process. The last phase was important to implementing continuous improvement practices in their learning process. Recently, their name was changed from "euniversity" to "smart university" to achieve its aspiration of becoming "a university of first choice in the Arab World [51]." The name change included changing the strategic plan to keep up with the latest advances in technological innovation.

\subsubsection{Kingdome of Saudi Arabia (KSA):}

The Saudi government offered online courses for the first time in 2002 [52]. These courses are designed for people who are interested in technical and vocational training. In order to ensure the success of this program, Center of e-learning training resources is established and created an electronic library with more than 50,000 books and 3,000 training programs [53]. In 2003, universities such as Um AlQura University and King Fahad University of Petroleum and Minerals established e-learning centers to support traditional programs to benefit from instructional technology by offering blended courses [54]. In 2007, the National Center for E-learning (NCEL) was established to support e-learning systems, but there was no online programs offered or accredited [55]. In 2009, the Ministry of Higher Education and NCEL organized the first international conference about e-learning and announced their acceptance of online programs [56]. Later, in 2010, the Ministry of Higher Education officially approved the online programs offered in the Saudi universities [52]. In 2011, the Saudi Electronic University was established as the first electronic university in the country to offer fully online and blended programs with collaboration from institutions such as eCampus Ohio University, University of Phoenix, Franklin University, Capella University, and Walden University [57]. Now, the university is in the process of achieving accreditation by national and international organizations to improve their quality of education and keep up to date with advancements in technologies.

\subsection{Strategy to implement online education}

In this section, a 5-step strategy for establishing online programs is provided. This strategy might help institutions in the Middle East to start their online programs. The first step is establishing a committee that consists of members of universities that value online education and have the passion to achieve this goal. This committee will act as a consummate resource to promote online education. The second step is to meet with administrators to convince them of the impact of online education on the society and explain the quality processes that can ensure the rigor of the education process. Step three is to develop collaboration with international and national organizations.

This collaboration will help to secure the funds needed to purchase technological infrastructures and train faculty and students. Many international organizations are offering funds to support education in the Middle East. One example of a collaboration has have been done in the Middle East area is that between the United Nations Educational, Scientific and Cultural Organization (UNESCO) and HBMSU in Dubai [58]. This also can be achieved by offering joint programs with American universities that have experience with offering online programs. The period for offering joint programs can be considered training experience for those universities which are interested in offering online programs for the first time. This period will help them to avoid any challenge that they might face once they are on their own. Step four is to work with administrators to establish standards, guidelines, and regulations that ensure the quality of online programs offerings. The last step is to establish quality assurance programs to ensure the continuous improvement of the learning process for the online programs. Figure 2 provides a model that summarizes this strategy. 


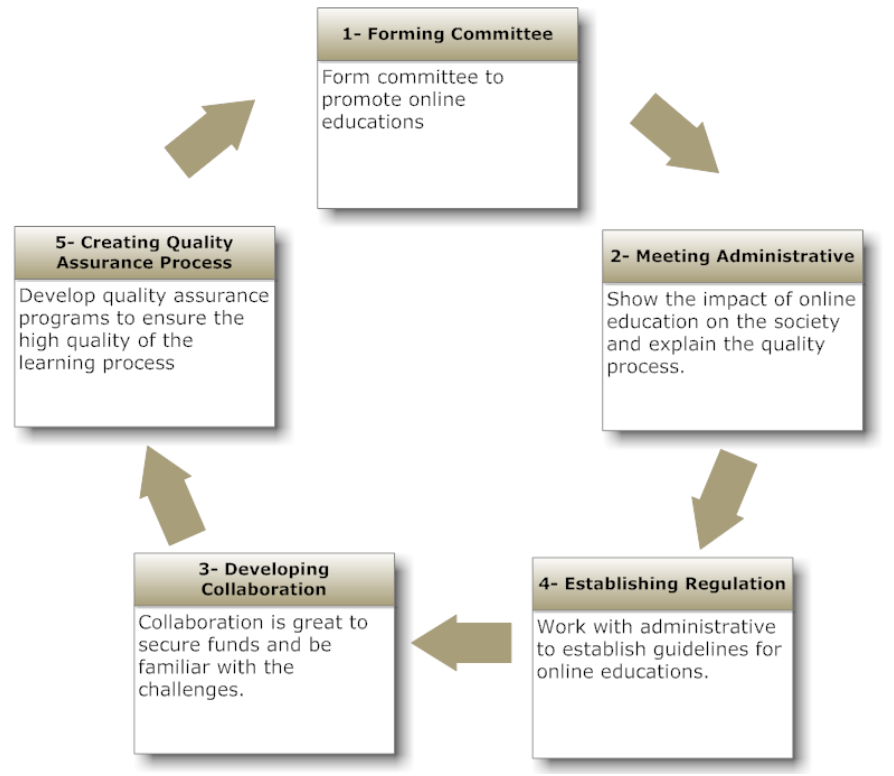

Figure 2. Model for implementing online education

\section{CONCLUSION}

Developing new online programs in the Middle East universities could be a challenge, but having a well-established technology infrastructure would make the process less challenging. Most Arab universities are offering blended courses as a strategy to enhance the quality of their traditional courses. Also, there are many academic programs offered with collaboration from experienced universities in the US and Europe. The researcher believes that universities in the Middle East are ready to implement online programs. The next step will be establishing government guidelines and standards to regulate the establishment of online programs and to ensure their high quality. Once these policies are in place, interested institutions should offer training to their faculty and students. Pursuing accreditation and collaboration with assessment organizations should be included in their strategic plans and should be achieved within 3-5 years. Monitoring and improving practices is important to ensure the continues improvement of the learning process and to keep up with emerging technologies.

\section{ACKNOWLEDGEMENTS}

The auther would like to thank Dr. Jim Barta the dean of College of Art, Education, and Humanities at Bemidji State University for his contribution in reviwing this research and providing important insites to be considered in this research.

\section{REFERENCES}

[1] C. Christensen and H. Eyring, "The top five ways universities can innovate to survive and thrive," 2011. [Online]. Available: http://hechingerreport.org/the-top-five-ways-universities-can-innovate-to-survive-and-thrive/.

[2] P. D. Coleman, R. Walker, L. Lawrence, "The pros and cons of education budget cuts: An investigative study," Research in Higher Education Journal, pp. 1-10, 2011.

[3] I. E. Allen and J. Seaman, Making the Grade- Online Education in the United States, 2006, Needham, MA: Sloan Consortium, 2007.

[4] Babson Survey Research Group, "Grade Level- Tracking Online Education in The United States," Babson Survey Research Group and Quahog Research Group, LLC., 2015.

[5] Online Learning Consortium, "Babson Study: Distance Education Enrollment Growth Continues," 09 Feb 2016. [Online]. Available: https://onlinelearningconsortium.org/news_item/babson-study-distance-education-enrollmentgrowth-continues-2/.

[6] U.S. Department of Education, "Evaluation of Evidence-Based Practices in Online Learning: A Meta-Analysis and Review of Online Learning Studies," Department's Alternate Format Center, Washington, D.C, 2010. 
[7] NCES, "Distance learning - Fast Facts," National Center for Education Statistics (NCES), 2014.

[8] Docebo, "eLearning Market Trends and Forecast 2017-2021," Docebo, Toronto, ON, 2016.

[9] The National, "UAE releases list of accredited foreign online universities," 15 Feb 2014. [Online]. Available: https://www.thenational.ae/uae/education/uae-releases-list-of-accredited-foreign-online-universities-1.310135.

[10] J. A. Spinks and K. Bedi, "Experiences of Creating E-Learning Programs in the Middle East," Middle East Institute, Washington, DC, 2012.

[11] A. A. Mirza and M. Al-Abdulkareem, "Models of e-learning adopted in the Middle East," Applied Computing and Informatics, vol. 9, no. 2, pp. 83-93, 2011.

[12] A. Ya Ni, "Comparing the Effectiveness of Classroom and Online Learning: Teaching Research Methods," Journal of Public Affairs Education, vol. 19, no. 2, pp. 199-215, 2007.

[13] Hanover Research, "Best Practices in Online Teaching Strategies," Hanover Research, Washington, DC, 2009.

[14] Davis Educational Foundation, "An Inquiry into the Rising Cost of Higher Education," Davis Educational Foundation, Yarmouth ME, 2012.

[15] TICAS, "Unpacking California College Affordability: Experts Weigh in on Strengths, Challenges, and Implications.," The Institute for College Access \& Success (TICAS), 2018.

[16] Open Education Database, "Online Colleges That Offer Laptops and iPads," 2018. [Online]. Available: http://oedb.org/ilibrarian/online-colleges-offering-free-laptops-ipads/.

[17] Aitken, "The Topic No One Wants to Consider: Faculty Time Management Online," 23 March 2015. [Online]. Available: https://onlinelearningconsortium.org/topic-no-one-wants-consider-faculty-time-management-online/.

[18] K. Shraim and H. Crompton, "Perceptions of Using Smart Mobile Devices in Higher Education Teaching: A Case Study from Palestine," Contemporary Educational Technology, pp. 301-318, 2015.

[19] L. C. Ragan, "Establishing Online Instructor Performance Best Practices and Expectations," Magna Publications, Inc., Madison, Wisconsin, 2018.

[20] B. Stern, "A comparison of online and face-to-face instruction in an undergraduate," Contemporary Issues in Technology and Teacher, vol. 4, no. 2, pp. 196-213, 2004.

[21] S. A. Riggs and K. E. Linder, "Actively Engaging Students in Asynchronous Online Classes," Oregon State University Ecampus, Manhattan, KS, 2016.

[22] J. Moloney, "Scaling Online Education: Increasing Access to Higher Education," Journal of Asynchronous Learning Networks, vol. 14, no. 1, pp. 55-70, 2010.

[23] State University System of Florida, "The Cost of Online Education," State University System of Florida, Florida, 2016

[24] S. Vonderwell and J. Savery, "Online Learning: Student Role and Readiness," The Turkish Online Journal of Educational Technology, pp. 38-42, 2004.

[25] Connecticut Distance Learning Consortium, "Students' Experiences in Online Courses," Connecticut Distance Learning Consortium, New Britain, CT, 2002.

[26] A. Ali and D. Smith, "Comparing Social Isolation Effects on Students Attrition in Online Versus Face-to-Face Courses in Computer Literacy," Issues in Informing Science and Information Technology, vol. 12, no. 1, pp. 11-20, 2015.

[27] T. Sitzmann, K. Ely, B. S. Bell, K. Bauer, "The Effects of Technical Difficulties on Learning and Attrition during Online Training," Journal of Experimental Psychology: Applied, vol. 16, no. 3, pp. 281-292, 2010.

[28] R. Epper and T. Bates, Teaching Faculty how to Use Technology: Best Practices from Leading Institutions, Westport, CT: Rowman \& Littlefield Publishers, 2001.

[29] K. Sibley and R. Whitaker, "Engaging Faculty in Online Education," 16 March 2015. [Online]. Available: https://er.educause.edu/articles/2015/3/engaging-faculty-in-online-education.

[30] Center for Educational Innovation- UMN, "Time and Cost Considerations in Developing an Online Course," 20 Feb 2015. [Online]. Available: https://cei.umn.edu/support-services/online-learning/time-and-cost-considerationsdeveloping-online-course.

[31] M. T. Eskey and M. Schulte, "What Online College Students Say About Online Instructors and What do Online Faculty Members Say About Online Instruction: A Comparison of Attitudes," Journal of Online Education, pp. 1-20, 2010.

[32] S. Bartolic-Zlomislic and A. Bates, "Assessing the Costs and Benefits of TeleLearning: A Case Study from the University of British Columbia," The University of British Columbia, Vancouver, British Columbia, CA, 1999.

[33] S. De La Rosa, "Wanted: Tech Support 24/7," 5 April 2017. [Online]. Available: https://www.insidehighered.com/digital-learning/article/2017/04/05/tech-help-online-programs.

[34] J. Weingarten, "MOOCs - What Exactly Are They?," 8 Sep 2016. [Online]. Available: https://www.distancelearningportal.com/articles/401/moocs-what-exactly-are-they.html. 
[35] N. Ö. Keskin, A. Koutropoulos, I. d. Waard, D. Metcalf, M. Gallagher, Y. Anzai and K. Buyuk, "National Strategies for OER and MOOCs From 2010 to 2020: Canada, Japan, South Korea, Turkey, UK, and USA," Administrative Leadership in Open and Distance Learning Programs- igi-global, pp. 1-25, 2018.

[36] J. Friedman, "5 Reasons to Consider Paying for a MOOC Verified Certificate," 4 March 2016. [Online]. Available: https://www.usnews.com/education/online-education/articles/2016-03-04/5-reasons-to-consider-paying-for-a-moocverified-certificate.

[37] D2L Corporation, "Brightspace Pulse Mobile App for Students," 2018. [Online]. Available: https://www.d2l.com/products/pulse/.

[38] Blackboard, "Mobile Learn," 2018. [Online]. Available: https://help.blackboard.com/Mobile_Learn.

[39] Canvaslms, "Mobile Guides - Canvas Student," 2018. [Online]. Available: https://community.canvaslms.com/docs/DOC-4048-mobile-guides-canvas-by-instructure.

[40] S. Burgstahler, "ADA Compliance for Online Course Design," 30 Jan 2017. [Online]. Available: https://er.educause.edu/articles/2017/1/ada-compliance-for-online-course-design.

[41] University of Washington, "Accessible Technology at the UW," 2018. [Online]. Available: https://www.washington.edu/accessibility/videos/.

[42] D. Douglas-Gabriel, "Why so many students are spending six years getting a college degree," 2 Dec 2014. [Online]. Available: https://www.washingtonpost.com/news/wonk/wp/2014/12/02/why-so-many-students-are-spending-sixyears-getting-a-college-degree/?utm_term $=.25 \mathrm{f} 8 \mathrm{c} 9 \mathrm{f} 86818$.

[43] H. Yue and X. Fu, "Rethinking Graduation and Time to Degree: A Fresh Perspective," Research in Higher Education, vol. 58, no. 2, pp. 184-213, 2017.

[44] Academic Partnerships, "A Guide to Quality in Online Learning," Academic Partnerships, Mountain View, California, 2014.

[45] R. C. Dickeson, "The Need for Accreditation Reform," U.S. Department of Education, Washington, D.C., 2007.

[46] D. Porcaro, "Arab Open and Virtual," International Higher Education, vol. 1, no. 59, pp. 23-25, 2009.

[47] HBMSU, "Research Based University," 2018. [Online]. Available: https://www.hbmsu.ac.ae/research/researchstrategy.

[48] Center for Excellence and Governance, "About Hamdan Bin Mohammed Smart University," HBMSU, 2018.

[49] L. Vrazalic, R. MacGregor, D. Behl and J. Fitzgerald, "E-learning Barriers in the United Arab Emirates: Preliminary Results from an Empirical Investigation," IBIMA Business Review, vol. 4, no. 1, pp. 1-7, 2009.

[50] HBMSU, "Publishing House," 2018. [Online]. Available: https://www.hbmsu.ac.ae/research/publishing-house.

[51] HBMSU, "HBMeU's Board of Governors looks into preparations to receive first batch of Ph.D. learners," 1 Aug 2013. [Online]. Available: https://www.hbmsu.ac.ae/news/hbmeu\%E2\%80\%99s-board-of-governors-looks-intopreparations-to-receive-first-batch-of-ph-d-learners.

[52] A. Al-Asmari and M. Rabb Khan, "E-learning in Saudi Arabia: Past, Present and Future," Near and Middle Eastern Journal of Research in Education, vol. 2, no. 1, pp. 1-11, 2014.

[53] H. S. Al-Khalifa, "E-Learning and ICT Integration in Colleges and Universities in Saudi Arabia," eLearn Magazine, New York, NY, 2010.

[54] A. S. Weber and S. Hamlaoui, E-Learning in the Middle East and North Africa (MENA) Region, USA: Springer, 2018.

[55] The National Center for e-Learning, "The National Center for e-Learning and Distance Learning," 22 March 2018. [Online]. Available: http://www.elc.edu.sa/?q=en/aboutus.

[56] M. M. Alsofyani, B. b. Aris and R. Eynon, "A Preliminary Evaluation of a Short Online Training Workshop for TPACK Development," International Journal of Teaching and Learning in Higher Education, vol. 25, no. 1, pp. 118-128, 2013.

[57] Saudi Electronic University, "About SEU," 22 March 2018. [Online]. Available: https://seu.edu.sa/sites/en/AboutSEU/Pages/HistoryTimeline.aspx.

[58] MENA Herald, "HBMSU \& UNESCO inaugurate second batch of 'Curriculum Diploma Program in the Arab Region'," 17 Jan 2018. [Online]. Available: https://www.menaherald.com/en/business/education/hbmsu-unescoinaugurate-second-batch-\%E2\%80\%98curriculum-diploma-program-arab-region\%E2\%80\%99. 